\title{
Research of the raise rent-seeking model based on electricity
}

\author{
Li Zhanping ${ }^{1,}$, , Yang Yubing ${ }^{* 1, b}$ \\ ${ }^{1}$ Ningbo DaHongYing University, Zhejiang 315175, China \\ ayybljf@163.com, ${ }^{b} 79632032 @ q q . c o m$
}

Keywords: Land Circulation, Electricity, the Raise, Rent-seeking.

\begin{abstract}
With the current three mainly forms of land circulation, this paper analysis the advantages and disadvantages of the three forms. Combined with the electricity and the raise, put forward a new land circulation mode of the raise rent-seeking based on electricity. Using this model, not only can solve the problem of growers upfront financing, but also can solve the problem of agricultural products sales. This model can greatly enhance the income of farmers or land contractors, growers.
\end{abstract}

\section{Introduction}

On November 20,2014, general office of the central committee of the communist party of China and the general office of the state council issued "About guiding rural land management rights transfer with the opinions of the moderate development of agricultural scale operation"[1]. "Opinions" the guiding ideology: comprehensive and accurate grasp the spirit of the central about comprehensively deepen rural reform. In order to ensure national food security, promote agricultural efficiency and farmers' income as the goal, adhere to the rural land collective ownership, ownership, contract right, management of division and separation. Guide the orderly circulation of land management, adhere to the basic position, family-run actively cultivate new operators, develop various forms of moderate scale management, consolidate and improve the basic rural operation system.

"Opinions" mentioned in "Separation of the three powers", refers to the "collective ownership of land, land management right to contract, farmers" separation of powers, to revitalize the land use right, improve the efficiency of land use, increase farmers' income.

\section{Current situation of land circulation in domestic}

At present land circulation mainly has the following several kinds of forms: 1, directly by the farmers contracted to large agricultural production enterprises or production plant. 2, by similar platform of "Tuliu website"[2], through the online trading, contract the land of peasants registration to agricultural production or manufacture large plant. 3, similar to the form of land joint-stock cooperative of Hefei Feixi county town Xinmin community[3], which is collected farmers with land to become a shareholder, unified management of land, and to subcontract the land to agricultural enterprises or production of large planting, finally produce large agricultural companies hire farmers to plant.

Form 1 is more traditional, relative to the comparison of land circulation before, through scale operate. This kind of form can reduce cost and increase the land utilization ratio and efficiency. Shortcoming is also very obvious, because the land is contracted to enterprise or planting large directly or planting large relative enterprises, due to information asymmetry. The weakness of the scattered farmers in absolute, it is hard to guarantee the interests of farmers.

Form 2 and form 3 is relatively new, with a third party (similar to "Tuliu website" platform or cooperatives) support, land lease price will be more reasonable which can guarantee the farmer's land rental income. Defect is due to land growers are mainly responsible for agricultural production, and can't decide sales of agricultural products which will bring two aspects: one is unpredictable agricultural prices, it is difficult to ensure marketable, also it is difficult to guarantee the land farmers 
interests; two is to pass circulation because from production to sales, many profit will be loosed in the circulation, so it's affect the interests of farmers, too.

In order to improve the income of farmers or contractors, at present there is a new form of scattered land rent-seeking, such as the "family farm" in Zhejiang Shaoxing which recognize a land farming by 600 yuan[4]. Form of scattered land rent-seeking by farmers, contractors, or network is introduced through acquaintances, scatter the land rent to city persons. By city persons or proxy planting, farmers or contractors unified management, produce the final directly to the lessee in city persons. This form overcomes the drawback of the second and third forms, namely direct connect growers and consumers together, make the form to increase farmer's income as much as possible. But the form has drawbacks as well as, the disadvantage is that because the form most confined to an acquaintance, farmers or contractors to sublet the land information is difficult to be widely told that this also caused can't form scale; Also because of the lack of unified management platform and the quality guarantee system, farmers the lessee or contractors, and city persons are very difficult to establish a reliable trust mechanism, so there is no guaranteed effect.

\section{Theoretical basis}

C2C E-commerce platform. C2C (Customer to Customer) model for e-commerce is the seller to the consumer [5]. In $\mathrm{C} 2 \mathrm{C}$ market, in addition to the buyer and the seller, there is an e-commerce trading platform provider. It is responsible for the supervision and management of buyers and sellers of the good faith, to fully monitor trading behavior, avoid fraud, etc., which can protect the rights of the buyer and the seller. $\mathrm{C} 2 \mathrm{C}$ e-commerce model embodies the Internet across regions, the spirit of online 24 hours a day. This mode has played a large network coverage, the number of users more advantage. Although looks $\mathrm{C} 2 \mathrm{C}$ e-commerce transaction process is similar to the auction market, but compared with the traditional second-hand market, it is no longer limited by time and space, save a lot of market communication cost. So it not only attracted a large number of users, but also can bring real benefits to the user. $\mathrm{C} 2 \mathrm{C}$ e-commerce model of benefit is not only the buyer and the seller, and providers who provide trading environment of electronic trading platform, such as taobao. Figure 1 is $\mathrm{C} 2 \mathrm{C}$ e-commerce sites action model.

The raise business model. The raise is a kind of Web3.0 in a sense. It makes the social network and "the majority of people support a few" fundraising way crossing[6], which makes the financing ways and means possible by P2B or P2P platform of protocol mechanism between different individuals. Building the raise business model needs three components of the project sponsor (raise people), public (investor) and intermediary institutions (the platform).

The process of the raise business model is such as figure 2 .

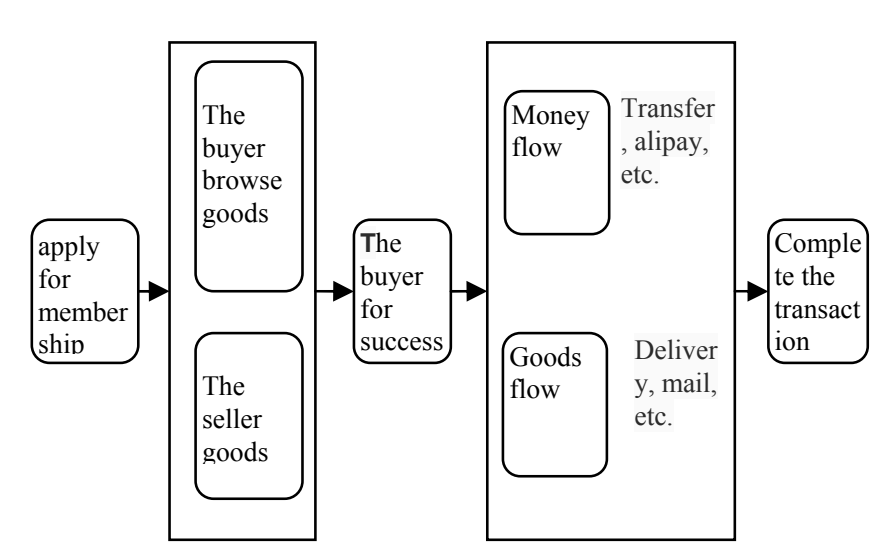

Figure 1. C2C e-commerce sites action model

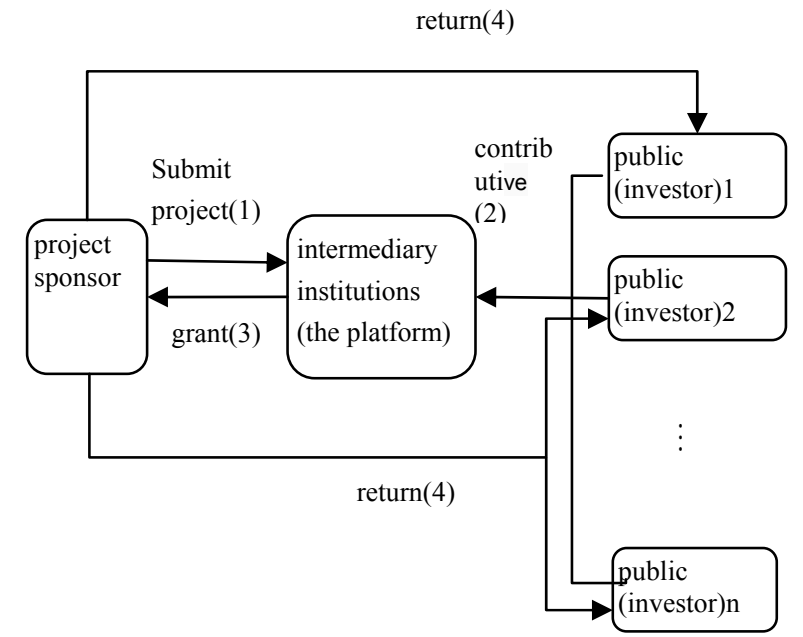

Figure 2. the process of the raise business model 
Land lease. Land lease is a kind of economic activity of a land owner and land user in a certain period of phase separation, the land user pays the rent during the use of land to the land owners, after the expiration of the land user return the land.

With the development of national economy, the famers who bound on the land have the opportunity to gradually out of the villages living in by ancestors, in order to pursue greater economic benefits and a more wonderful life. Most of China's rural land circulations take the form of a lease. Farmers or farm households make leasing decisions, the economic reason behind it is contrast of farmland leasing income before and after. This can be consider from the farmers' land lease cost effectiveness and its retained earnings and other factors. Accordingly, we can set up farm households (or farmers) land leasing decision (will) function [7], its function can be expressed in the type:

$\mathrm{D}(\mathrm{R})=\mathrm{P}(\mathrm{I}-\mathrm{C}>\mathrm{R})$

Type of $\mathrm{D}(\mathrm{R})$ for farmers land leasing decision function; $\mathrm{I}$ is the land leasing revenue, including land rent into and out of income; $\mathrm{C}$ is the cost of land lease, including land rent into and out of cost; $\mathrm{R}$ is the farmers reserved income.

\section{Put forward of the raise rent-seeking model based on electricity}

In order to solve the above problems, we need to create a "electricity raise rent-seeking" mode of land circulation. The electricity raise rent-seeking model is on the e-commerce platform, the contractor divide one land into more according to a standard, then rent in the form of goods. City persons also can know the information of renting land by this platform, and rent it. In the process of the rent recognition, city persons but also can put forward to the cultivation of agricultural products, the requirements on the use of pesticides and fertilizers, etc. Once the rent is ok, city persons need to pay the rent. City persons can plant by themselves, which can also instead of planting by the contractors. City persons can be shown through the network platform agricultural growth in ordinary times. At last, the agricultural products belong to city people. This model likes as figure 3 . This mode has the following two aspects:

(1) Direct integration of two links of industrial agricultural production and consumption patterns, and direct docking producers and consumers, which is one expansion mode of "Separation of the three powers", it belongs to the industrial innovation.

(2) Technology of the raise, the Internet finance and electric business platform have been integrated into land circulation, the production and consumption, which achieved get money of agricultural production by the raise rent land, it is a novel way of rural finance, and also is one of the Internet financial innovation.
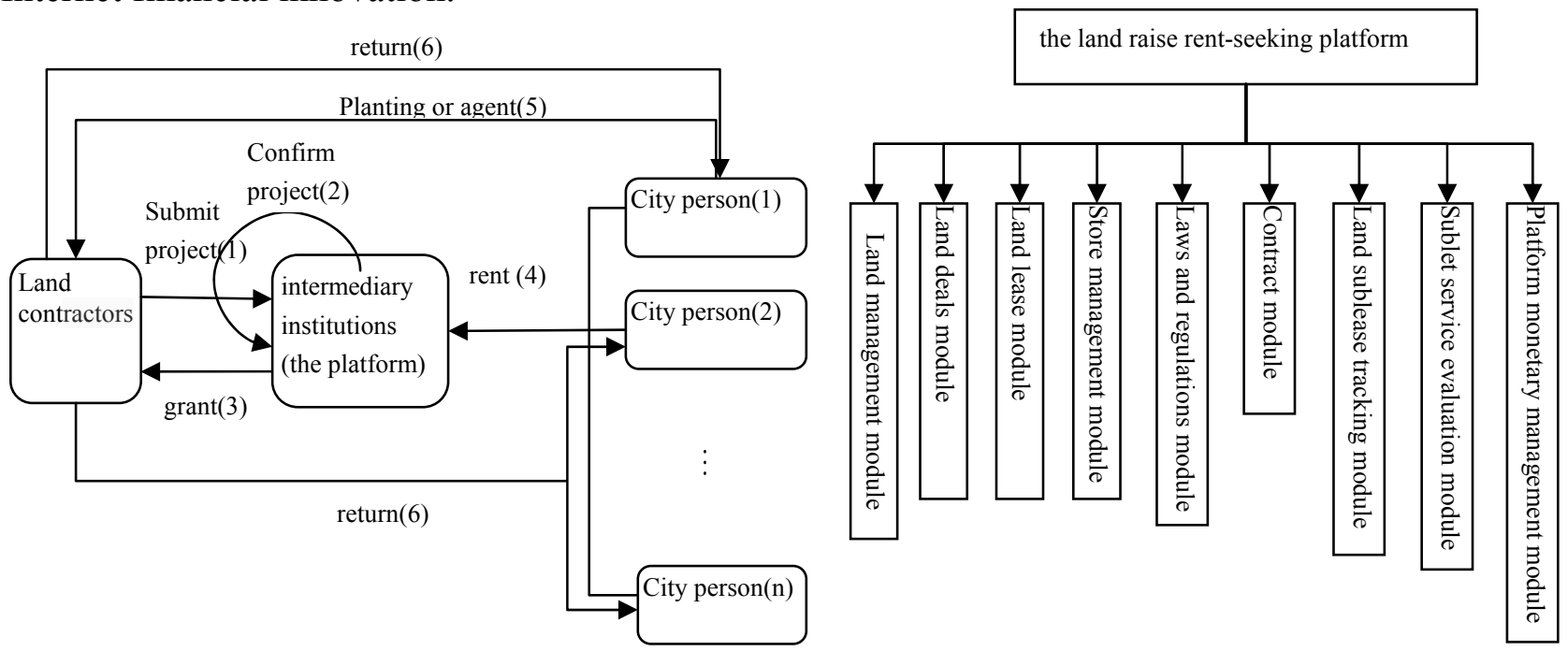

Figure 3. the raise rent-seeking model based on electricity Figure 4. basic function modules in this platform 


\section{Put forward the platform construction plan}

Follow the software engineering standard, put forward the platform construction plan of the electricity raise land rent model on the basis of the Internet.

Software engineering specification process: from the project feasibility analysis $->$ demand analysis $->$ system analysis and design $->$ system $->$ system testing. This platform construction plan will start from the software engineering standard flow, analyzed step by step. Finally, we get a relatively complete plan of feasibility analysis, requirement analysis and system analysis design.

Platform basic module functions, such as in figure 4:

Function modules' brief description:

a. Land management module: including land information registration, cancellation, etc.

b. Land deals module: including land appearance, land subcontracting, etc.

c. Land lease module: including land lease, land raise and rent, etc.

d. Store management module: including store's information, store may be farmer, contractor, or agent.

e. Laws and regulations module: including advertise of laws and regulations.

f. Contract module: there should be contracted in process of land subcontract between farmer and contractor or land rent between contractor and renter.

g. Land sublease tracking module: including tracking of the land sales process, agricultural production process.

h. Sublet service evaluation module: the same as evaluation of goods after-sales service of taobao C2C. Renter can evaluate contractor, contractor can evaluate renter, too. There are two phases in the process of evaluation: phase of sublet and phase of agricultural harvest.

i. Platform monetary management module: including module of money into and money out.

\section{Summary}

The raise rent-seeking based on the electricity is an Internet thinking mode of land circulation, which use of e-commerce platform, combined with the raise pattern of agricultural products futures, and integrate agriculture industry chain. This mode not only realizes the agricultural production and the consumption of agricultural direct docking, but also realizes the abnormal growth of farmers' income.

\section{References}

[1] Print by Centre Office, Country Office "About guiding rural land management rights transfer with the opinions of the moderate development of agricultural scale operation". China's agricultural news. 2014-11-20.

[2] Information on http://www.tuliu.com/

[3] Information on http://www.tuliu.com/read-8617.html

[4] Information on http://finance.chinanews.com/cj/2014/03-26/5997493.shtml.

[5] Zhao Ran. Research on business model of C2C third party e-commerce platform[D]. Beijing: Capital Univercity of Economics and Business, 2009.3.

[6] Fan Jiachen. Research on the raise of business model[J]. Enterprise economic, 2013,8:72-75.

[7] Zhong Taiyang. Land Property Rigits and Farmer Households' Willingness of Farm Land Leasing[J]. China Land Science, 2005,2(19):50-55.

[8] Zhi-qiang shi. The comparison and reference of foreign land circulation system[J]. The southeast academic, 2009(2):69-73. 